\title{
Aesthetics of Postmodernism in Clifton Gachagua's Madman at Kilifi
}

\author{
Adelokun Adetunji Oluwapelumi \\ Department of English, Skyline University Nigeria \\ adetunjiadelokun@gmail.com
}

DOI: http://doi.org/ 10.36892/ijlls.v3i2.548

\begin{tabular}{|c|c|}
\hline $\begin{array}{l}\text { Received: } \\
27 / 0 / 2021\end{array}$ & $\begin{array}{l}\text { Abstract } \\
\text { This study is an attempt to analyse the postmodern aesthetics of the poetry }\end{array}$ \\
\hline $\begin{array}{l}\text { Accepted: } \\
15 / 05 / 2021\end{array}$ & $\begin{array}{l}\text { collection of Clifton Gachagua. This analysis was informed by the need to } \\
\text { critically identify the structure of postmodern writing and the tenets of } \\
\text { postmodernism which informs the creative imagination of Clifton Gachagua } \\
\text { in Madman at Kilifi. This study critically appraised the manifestation of }\end{array}$ \\
\hline $\begin{array}{l}\text { Keywords: } \\
\text { Postmodernism, } \\
\text { East African } \\
\text { poetry, Aesthetics, } \\
\text { Madman at Kilifi }\end{array}$ & $\begin{array}{l}\text { intertextuality, meaninglessness of meaning (populism), scatological imaging } \\
\text { and formlessness in the poetry collection. The study revealed that the poetry } \\
\text { collection is a reflection of Clifton Gachagua's postmodernist inclination and } \\
\text { masses oriented ideologies. The poet amplifies the need to advocate the } \\
\text { dominance of consumerism and the urgent need to denounce globalization. }\end{array}$ \\
\hline
\end{tabular}

\section{INTRODUCTION}

Postmodernism is considered to be an offshoot of the realities of the Second World War which ravaged the globe and changed the face of humanity forever. The changes were also evident in the literary circle as it influenced the creative imaginations of writers globally. The literary indoctrination paved the way for skeptical apprehension of cultural dialectics, philosophy of existence, historical realities, fictional identities as well as artistic ingenuity. Postmodernism served as a response to the idealistic construct of the modernist perspective of literary creativity. Hence, a lot of views which were hitherto strengthening the straightjacketed approach to enlightenment and humanism.

If critical explications into the theory of postmodernism like (Fielder,1971; Hassan, (1985;1989) Morris, 1988; Jacques, 1989; Harvey 1989; Jameson, 1991; Hall, 1996; Browitt, 2002; Butler, 2002) are anything to go by, it is not out of place to state that the origin of the literary theory known as postmodernism, cannot be pigeonholed into a particular period of time. According to Butler (2002), postmodernism

does not simply support aesthetic 'isms' or avant-garde movements, such as minimalism or conceptualism... (which has) a distinct way of seeing the world as a whole, and use a set of philosophical ideas that not only support an aesthetic but also analyse a late capitalist cultural condition of postmodernity. (p.5)

Although the prefix 'post' in postmodernism serves the same function like the prefix in poststructuralism, postmodernism cannot be rigidly discussed under a historical headline. In other words, postmodernism seeks to re-present the ethos of modernism by consolidating, and other times, confuting the tenets of modernism. Consequently, the word 'post' in literary scholarship does not necessarily infer 'a period after', although, 'a period after' is just one of its meanings. Postmodernism in literary scholarship is an epistemological inquiry into how 
new and innovative patterns of viewing age, time, and space have informed the creative imagination of literary artists. However, this definition cannot be said to exclusively encompass what postmodernism actually means. It dawns on us at this point, to critically understand the word 'modernism' as it informed advances into postmodernism.

Scholars have sought to critically appraise the term, 'modernism'. They see it as a coinage which defines the renaissance ushered in by effects of the two world wars. The common opinion in literary scholarship is that the aftermath of the two world wars, considerably influenced literary activities, as artists began to explore new patterns of seeing the world.

Owing to this, critics have also maintained that postmodernism, is a reaction to modernist ethos. It seeks not to only corroborate modernism but also confute some of its ethos. Little wonder, Storey (2001) in his explication on the literary convention and theory of postmodernism, contends that; "postmodernism is an attack on modernist elitism". It rejects all established modernist features (p. 147).

In the same vein, Akin (2012) and Malpas (2005) stress the areas where postmodernism refrains from modernism ethos, when they avow that; "postmodernism focuses its attack on modernist ethos such as unity, order, truth and knowledge, giving way to postmodernist ethos like; fragmentation, fracture, indeterminism and plurality".

Curl (1999) contends that; postmodernism installs the 'laws of faith' in what we once apprehended as certainties. In his opinion, the theory considerably advocates cynicism, fragmentation and ill-digested eclecticism. The literary theory articulates its non-conformist nature, as it critiques ideas like; order and meaning in the society and leaves the readers with the wherewithal to critically dissect texts for exclusive comprehension of meaning.

Postmodernist poetry relies on the literary ability and creative ingenuity of poets to impeccably depict existentialist images in the creation of reality. It also extols ambiguity of diction to encode 'writerly' intentions for 'readerly' comprehension. Thus, poets articulate their perceptions about the postmodern condition through non-conventionalized means. In achieving this, poets employ ambiguity and existential themes, which imminently shapes the understanding of the poetic vision by the readers. Through this style, poets are able to forebode the disillusionment and nihilism which characterize the postmodern society.

The import of irony in postmodernist poetics cannot be overemphasized. Critics identify the aesthetics of classical Greek tragedy to be aided by the use of irony. Bearing this precedence in mind, postmodernist modern African poets, address the sociological realities in their representative milieus, through the use of paradoxical and ironic elements.

\section{THEORETICAL BACKGROUND}

The basis for the evolution of postmodernism as a theory of academic inquiry is a significant epistemological shift in how we see and know the world. (Gregory-Castle, 2007). Corroboratively, Krishan Kumar (2009) suggests that postmodernism should be appraised on the basis of its criticism of the modernist ethos, in order to proffer necessary improvements. Thus, the prefix 'post' in postmodernism does not readily mean 'post-modernism' or 'aftermodernism but a revolutionary, yet innovative change in the technologies and art of writing. (p. 144). Jean-Francois Lyotard (1984), states that "the postmodern world would be that which, in the modern, puts forward the unpresentable in presentation itself, that which denies itself the solace of good forms" (p. 81).

Postmodernism highlights the essence of fragmentation, indeterminism, irony, plurality, parody, mimetic skepticism, pastiche (intertextuality), self-reflexivity, aestheticism, fabulation, paradoxical composition and cynicism. Intertextuality is defined as the textual influence a text has on another text. Texts are seen to have peculiar similarities with other texts. The postmodern tenet hinges on the deployment of pastiches and parodies in the construction of meaning in a text by other texts. The writer is consequently, a pivotal element in intertextual relationship between texts. Kristeva (1966) and Simmons (2013), were able to 
highlight the import of the writer's intention through the; obligatory, optional and accidental classifications of intertextuality.

Jacob Meyer (1998) suggests that: the onus is on the creative artist to fulfil the obligation of making the comprehension of text seemingly effortless by paying cognisance to what he refers as 'the hypertext.' Wohrle's (2012) submission is equally significant in the discourse of intertextuality. He makes a good case for the subconscious level of intertextuality. He contends that intertextuality could be derived from a different text other than that of the writer. He goes on to expatiate on the 'accidental' discovery of intertextuality which transcends the intentions of a writer as it materialises as a result of readers' prior knowledge.

Considering intertextuality from the perspective of the novel, Kehinde (2003), emphasise the need to jettison the term 'influence' in favour of 'intertextuality'. He posits that the author-centred notion which the term, 'influence' connotes, diminishes the aesthetic and creative intentions of the term, 'intertextuality'. He notes that the employment of the term 'intertextuality' instead of 'influence', does not undermine the place of the author, but contributes immensely to the value of the texts.

Kehinde (2003) goes further in identifying the place of the readers in 'intertextuality'. He describes intertextuality as a coinage which emphasises the import of the readers in literary creativity.

...the theory of intertextuality also depends on the reader as the organizing centre of interpretation. Again, for the Deconstructionist, intertextuality refers to both the relationship among literary texts and the dialogue between them and other writings... (p. 374).

This is akin to the view of Martin Coyle, when he posits that each text takes its meaning from other texts. The generation of meaning is not restricted to only texts written before the 'intertextualised' text, but other concomitant texts. In the same vein, (Barry, 1995) posits that, intertextuality in postmodernism, purports to examine "a major degree of reference between one text and another". In Kehinde's (2003) view,

...the scrutiny of the reference, the postmodernist critic privileges the abandonment of the divine pretensions of authorship... intertextuality is a creative means used to: Signify the multiple ways in which any one literary text echoes, or is inescapably linked to, other texts, whether by open or covert citations and allusions, or by the assimilation of the feature of an earlier text by a later text, or simply by participation in a common stock of literary codes and conventions.... (p. 375).

The postmodern literary tradition also amplifies the effect of the postmodern realities through the depiction of the meaninglessness of meaning in texts. This ensures that the art is used as a tool to showcase the indeterminacy of meaning of existence in a postmodern world. This principle elaborately criticizes the foundations of philosophies and ideologies and seeks to establish the dysfunctional pattern of fundamental beliefs and philosophies. Moreover, it amplifies the integration of the deconstructionist approach. This approach connotes that there can only be interpretations and not meanings of experiences. Hence, our perception about things are basically aided by our experiences.

Inadvertently, the experience of meaninglessness of meaning paves way for the discovery of the indeterminacy of structure or the formlessness of structure. Postmodernism enhances the depiction of fragmentation and the inability to ascribe form and structure to literary endeavours. It is perceived that their inability to establish a structure paves way for creative experimentations and expressions of ingenuities. This goes a long way to affirm the 
nature of postmodern reality as a society based on unrestricted depictions of vices. Hence literary endeavours can only capture the reality of this eventuality through the lens of unabated creativity and self-reflexivity.

The populist approach in postmodernism is enabled by the self-reflexive ability and wherewithal of literary artists to present and represent scenarios with the bottlenecks of conforming to established norms and conventions. This guarantees that the readers are granted the autonomy to critically appraise literary arts without any restrictions in their literary appreciation. This is not an avenue for misreading. However, it creates the avenue for intimate interface and interaction with literary work because the readers are not restricted by any form of critical appraisal formula.

\section{CLIFTON GACHAGUA'S LITERARY INDOCTRINATION}

Clifton Gachagua is one of the leading lights among the emergent poets of the $21^{\text {st }}$ century in the East African Literary tradition. His passion for writing innovative has endeared him to the hearts of literary scholars and critics. He is often regarded as one of the symbols of unprecedented societal evolution. His thematic indoctrination affirms his resolve to ensure that the postmodern realities and eventualities that his enabling milieu is exposed to are exposed and adequately comprehended by affected populace.

\section{ANALYSIS OF THE POSTMODERN TEMPER IN CLIFTON GACHAGUA'S MADMAN AT KILIFI}

\subsection{Intertextuality}

Madman at Kilifi is an emotional and self-reflexive purgation of poetic imagination and visions of Clifton Gachagua about his enabling milieu. This collection of poetry features fifty poems which represents the sensitive, whimsical and sardonic poetic observations of the poet about his society. Evidently, the poet relays the existential nature of the traditional culture and how the technological savvy world is gradually eroding the virtues which hitherto maintained sanity in the society.

The poetry collection draws considerable wealth of influence from literary texts written before it. The essence of interxtuality is the understanding that texts do not stand in isolation but a shares identity with other texts. Clifton Gachagua explored this postmodernist element to facilitate the creation of deductions and criticisms by the readers. It is evident that most of the intertextual relationship explored in this poetry collection do not take attention away from the theme of the text but only amplifies the purpose of the creative identity of the postmodern writer. At the Confucius Center recounts the unfortunate loss of identity and vision which most postmodernist writers have to grapple with due to their inability to transcend the negative influence of technology and affluence gained through tourism and globalization. The poet identifies and juxtaposes the comical lifestyles of these poets with the clownish acts in Quentin Tarantino films.

He fell in love with violence in books,

and the slapstick humor of crooks in Quentin Tarantino films.

He maintained an e- mail relationship with a gay pacifist

and second- year law student from Nairobi.

The intertextual reference highlights the notion of the poet and also amplifies the disconnection that exist between people who were meant to be vanguards of restoration and cohesion in the society have seemingly left their duty in favour of the advancements and the selfish pleasures. The poet also believes that the passivity in the attitude of the 'great philosophers' has only exposed the anomaly inherent in a world where the lip service is only paid to 'the coded passages from the postmodernists'. The poet also employs intertextuality whilst discussing the impact of technology on humanity in Reality Television. Here he 
establishes an intertextual connection between this poem and the Myth of Sisyphus. The poet highlights the danger of overtly limiting living experiences to technologically aided lifestyle. According to him, this will only consume the essence of communalism and also propagate the heinous nature of individualism. Apart from this, this new technology-aided lifestyle will only expose the fabrics of the society to vices which will eventually terminate virtues in the society.

We, as a minor infringement of the law,

we have spent all day sending each other messages

that might be riddles to our consciences, if we had any.

Messages like favorite sexual positions...

He highlights the danger inherent in the disregard for the impending danger that looms ahead if this trend of perpetually seeking solace in technological advancement is not properly monitored.

you are in the other room watching reality tv

about bad girls who live together and drink tequila all day.

I press on through the preface toward absurdity and suicide.

The deployment of intertextuality in this collection of poetry enables the readers to have a wider periscope whilst appreciating the creative imagination and vision of Clifton Gachagua.

\subsection{Meaninglessness of Meaning}

Postmodernism is a literary indoctrination that highlights the existentialist nature of human existence. It highlights the impossibility of situating meaning and wholly comprehending the pattern of human existence. Clifton Gachagua employs this tenet in Madman at Kilifi to highlight the nature of human living or existence in the postmodern Kenyan society. In Birds, Gachagua buttresses the theme of meaninglessness of meaning through the experiences of the poetic persona who seems to operate in a very unstructured and unhinged environment where everything that happens to him seem to be by chance and luck.

There is a house full of what you might call birds, species never before seen, some thought of as extinct. When I point out a bird by an all- weather road, instead of looking at it you look at me, you say it makes you happy to see me so taken in. I sight the same bird a week later, when you are not with me. I like this skin, that

The persona finds it difficult to grapple with the issues around him and all actions taken to ensure that he assert himself and ascertain the control of his immediate environment all end up in futility. The poetic persona can only cling to hope and luck to ensure that he is able to realize his dreams and aspirations

I swear to you, this is

no metaphor. The cold means flowers bloom slowly. Flowers

from your ears and mouth, like cotton on a dead body. There is dust in my eyes and I'd like you to lick it. There is music in my throat and I'd like you to kiss it. When I see the bird I will be seeing you, I will take you home, get into your skin.

The meaninglessness of meaning is also established in the notions expressed by the poet in Imitation Bodies. Gachagua highlights the reality of nurturing dreams and aspirations in a postmodern world. He presents the reality as a one which involves individuals who are caught in the web of lofty but unrealistic ambitions.

contemplating new and emerging markets for

the experiments we call dreams.

You forget when we invented a different language 
to be broadcast through touch.

He decries the inability of these individuals to realize that they are only functioning as imitation bodies who are destined to meet at the crossroad of recurrent manifestation of fate. This manifestation of fate always levels up their ambition and acts as a form of reality check for their inability to understand the pattern which their existence is structured.

Our eyes are now coated

in the mascara of strangers;

a film of gold

paves our vision as soon as a blink is possible.

The languages we are busy forgetting

is our only accomplice.

We are all strangers in this city, existential sheep in traffic.

The poet also highlights the existentialist nature of living and the meaninglessness that pervades the postmodern society through the poetic ideas shared in Madman at Kilifi. This poem depicts the nature of the postmodern society in full glare. Gachagua relays the alternate reality of postmodern existence which highlights the notion of meaninglessness of meaning through the activities of the renowned madman at Kilifi. He is known by all and sundry and enjoins reverence from those who have been in contact with him.

Gossamer in her eyes, my eyes.

We see algae on the walls on the small of her back.

He wears polythene bags around his girth, a

lost superhero of my lost childhood.

The meaninglessness of meaning in this poem is not only exemplified in the characterization of this renowned madman at Kilifi but can also be perceived in the identification of the sane traits of an insane individual who happens to be saner than sane people.

He means no harm. At the

intersection of a bank and wholesale shop he sits

contemplating the lovers

he sees walking, mad at each other.

The madman is also depicted as a harbinger of fond memories who the poet wants to linger perpetually in his memory because they shared a very sacred form of connection which seems to be unwavering and impossible to break. The solace the poet enjoys in the company of the madman clearly highlights the inevitable insanity that characterizes the bid to discover the meaning of a meaningless postmodern construct.

\subsection{Scatological Imaging}

The obscene nature of existence in the postmodern world is another tenet highlighted in Gachagua's collection of poetry. The poet identifies the disruption in sanity occasioned by the postmodern reality on humanity. In the postmodern world, it is evident that the fabric of the society which was held by high moral values and the perpetuation of virtues has been disrupted by obscene infiltrations and heinous manifestations. Hence, it is often not out of place to discover the utilization of scatological imagery, extreme perversions, queer tendencies and other form of antisocial and amoral tendencies in postmodernist literature. Gachagua highlights some of these scatological imagery through the diction, thematic focus and the characterization of the poetic personas in most of the poems in this poetry collection. Ghostwriter sets the stage for the literary indoctrination that characterizes postmodern literature. Gachagua identifies the effect of the postmodern lifestyle on postmodern literary output by brandishing the form of creative exigencies in postmodern literature.

(Adult Content) Ghostwriter for Erotic Stories and Paranormal 
Erotica Requires 6 hardcore erotic adult content short stories.

Payment will be a total of $\$ 150$ USD for this project.

no incest, rape, or...

Gachagua depicts the creative trajectory of postmodern writers who are conscripted to relate the realities of their enabling milieu through their creative imaginations. Consequently, these imaginations usually captures the destruction of virtues in the postmodern world and the engagement in all sorts of obscene vices.

This notion is also expressed in graphic details in On a Terrace Balcony in Abuja. The poet highlights sexual perversion and amoral inhibitions in this poem. The same report can also be said relayed in Algorithm, Desertion and New House.

The expression of sexual perversion and manifestations of queer tendencies in postmodern literary pieces is taken a notch higher in Young. In this poem, the poet associate the unbridled experimentation that characterized postmodern society with the acquisition of selfconsciousness and unguided independence. The mild reference to issues which were hitherto anathemas prior to the postmodern revolution in the world, shows the extent at which the society has lost its moral sanctity.

There was a time we needed to experiment

with drugs and jazz records, hallucinogens

and men, a long time ago...

Eventually, this loss of virtues in the postmodern world gave impetus for people to question age long traditions and subsequently started reconstructing perceptions about themselves. This paved way for the introduction of gay and queer tendencies in literature as the world of experimentation has given people the liberty to seek alternate knowledge about their reality.

These reappraisals informed the thematic preoccupations of some of the poems in this collection. Some of these poems include: Reclaiming a beloved City, The Antechamber, A genre of Isolation and The Latrine of Giardia. These poems are replete with scatological imagery which does not only reveal the physical state of destruction in the world but vividly portrays the level of rot in the social and moral aspects of the society.

\subsection{Formlessness}

The creative freedom endowed on the postmodern writer allows him or her to exercise unbridled and unconventional freedom to document his literary and creative imagination. However, it is noteworthy to highlight the fact that this freedom is not only limited to their thematic preoccupations which are relayed through their creative imagination. Literary writers are also enabled to experiment with the structure of their literary pieces to emphasize their notions and also showcase the nature of the society they depict in their creative pieces.

Formlessness is a unique feature of postmodernist poetry as it is used as a means of documenting fragmentations, visualization and juxtaposition of imagery. Formlessness in Gachagua's poetry enables the unrestricted comprehension of the poet's notions. It offers a range of perspectives on the ideologies being passed across by the poet to the readers. Hence, the nonconformist nature of postmodernist poets enables readers to generate nonconventional meanings about poetic compositions.

Gachagua adopts different varieties of experimentations that are alien to poetic style of writing. In The Nobel Prize for Medicine, Gachagua uses indentation to separate the ideas in the first line of the poem from the other lines. Apart form this, Gachagua also uses irregular line symmetry to explain his poetic visions in On a Terrace Balcony in Abuja. The line pattern in this poem is also without a definite pattern or structure. These aforementioned style are usually used in the prose narratives but the poet experimented with this style to showcase the narrative import of his poetry and the fact that he is bent on taking the readers on a narrative journey through the twist and turns of his poetic reasoning. 


\section{CONCLUSION}

Clifton Gachagua's Madman at Kilifi is a masterpiece which accentuates the postmodern aspects that characterize postmodern literature. It is a collection that comprehensively relays the aesthetics of postmodern poetry. It also identifies with the notion that postmodern experimentation, formlessness, intertextuality and the meaninglessness of meaning are not avenues for nonsensical poetry but media through which the art for life sake function of literature is established. This is the function that emergent poets in the East African literary tradition focus on in their poetry as they try to relate the effect of the postmodern realities on the sociopolitical existence of their enabling milieus. A conscious effort to discuss these realities is often made through the use of language, style and thematic preoccupations in the poetry collections of these poets. The readers are often exposed to the scatological nature of existence, the meaninglessness of existence and the indeterminacy of the structure of living.

\section{REFERENCES}

Barry, P. (1995). The beginning theory. Manchester: Manchester University press

Basada, D. J. L. ., \& Moyano, M. A. G. (2021). Breaking-Away from the Comfort Zones: Postmodernism in Selected Philippine Contemporary Novels in English. International Journal of Language and Literary Studies, 3(1), 130-150.

Bertens, H. (2001). Literary theory: the basics. New York: Routledge

Browitt, J. and Milner, A. (2002). Contemporary cultural theory; an introduction. Crow nest: Allen and unwin

Butler, C. (2002). Postmodernism. A very short introduction. United Kingdom: Oxford University press

Bright, F.O. (2013). Reflection of the Struggle for a Just Society in Selected Poems of Niyi Osundare and Mildred Kiconco Barya Language in India 13(6), 102-120

Castle, G. (2007). The Blackwell guide to literary theory. U.S.A: Blackwell publishers

Egudu, R.N. (1978). Modern African poetry and the African predicament. Hong Kong: Shanghai printing press limited

Ezenwa-Ohaeto, N. (2013). Minstrels never die: selected writings of Ngozi Ezenwa-Ohaeto.

Ibadan: Kraft Books limited

Fashina, N. (2009). Alienation and Revolutionary Vision in East African Post-Colonial Dramatic Literature. Ufahamu: A Journal of African Studies. 35(2) 1-31

Fielder, L. (1971). The culture of postmodernism- theory, culture and society. New York: Stein \& Day

Hall, D. (2001). Literary and Cultural Theory: From Basic Principles to Advanced Applications. New York: Houghton Mifflin Company

Harvey, D. (1989). The condition of postmodernity: an inquiry into the origins of cultural change. Oxford: Basil Blackwell

Hassan, I. (1989). Dictionary of cultural and critical theory. U.S.A: Blackwell publishers 
Heywood, C. (1971). Perspectives on African literature. London: Hienemann

Irele, A. And Gikandi, S. (2004). The Cambridge history of African and Caribbean literature. Cambridge: Cambridge university press

Jameson, F. (1991). Postmodernism, or, the cultural logic of late capitalism. England: Duke university press

Jones, E.D. (1982) African Literature today. Retrospect and prospect. London: Heinemann

Kehinde, A. (2003). Intertextuality and the Contemporary African Novel. Nordic Journal of African Studies, 12(3): 372-386.

Killiam, G.D. (1973). African writers on African writing. London: Hienemann

Klages, M. (2006). Literary Theory: A Guide for the Perplexed. London: Continuum

Kumar, K. (2009). From post industrial to postmodern society: new theories of the contemporary world. New Jersey: John Wiley and sons

Lyotard, J. (1984). The postmodern condition. Manchester: Manchester University press

Makhoka, Dipio and Kabaji (2011). East African literature; Essays on written and oral traditions. Berlin: Logos Verlag

Makhoka, J.K.S. (2011). Ethnic identities and gender themes in contemporary east African literature. A PhD dissertation. University of Berlin. Berlin

Malpas, S. (2005). The postmodern. New York: Routledge

Mason, F. (2007). Historical dictionary of postmodernist literature and theatre. Plymouth: Scarecrow press

Mazrui, A. A. (1986). The Africans: A Triple Heritage. London: BBC Publications

Olaniyi, A. 2012. A critique of the postmodern episteme in selected contemporary Nigerian

Novels. An unpublished thesis. University of Ibadan. Ibadan

Saavedra, J. (2004) Modernity or Adaptability? The Incorporation of Foreign Words into Swahili

Poetry. Trento: African World Press

Storey, J. (2001). Cultural theory and popular culture. New York: Routledge

Quayson, T. and Olaniyan, T. (2007). African literature; an anthology of theory and criticism.

Oxford: Blackwell publishers

Warren, K.W. (2010). What was African American Literature. American Studies. 55 (4) 739742

Wellek, R. and Warren, A. (1984). Theory of literature. New York: Harcourt 
William, D. And Kerfoot, A.L. (2008). Student encyclopedia of African literature. Westport and London: Greenwood press

\section{$\underline{\text { AUTHOR'S BIO }}$}

Adetunji, Oluwapelumi Adelokun is a lecturer who teaches English communication classes at Skyline University Nigeria. He is interested in African Literature, African-American Literature and postmodernist literature. 